\title{
Полякова М.Д. \\ Проблема интеграции дистанционного обучения в систему заочного образования в неязыковом вузе
}

\author{
МГОУ \\ (Россия, Москва)
}

doi: $10.18411 / \mathrm{j}-08-2021-49$

\section{Аннотация}

Статья объясняет понятия «заочное обучение», «дистанционное обучение», «дистанционные образовательные технологии»; выделяют проблемы заочного обучения в неязыковом вузе и пути его модернизации за счет интеграции средств дистанционного обучения в заочное. Дистанционные образовательные технологии описаны как способ осуществления контакта между преподавателем и студентами, как возможность удобного доступа к банкам информации, как способ повышения уровня мотивации обучающегося.

Ключевые слова: заочное обучение (3О), дистанционное обучение (ДО), дистанционные образовательные технологии (ДОТ), учебные Интернет-ресурсы, организация самостоятельной работы студента.

\section{Abstract}

The article gives explanation to the notions "learning by correspondence", "distance learning", "distance learning technologies". It outlines the problems of learning by correspondence in non-linguistic universities and ways to improve it using means of distance learning. Distance Learning Technologies are described as a means of realization of contact between the teacher and the students, as a possibility to have access to a large amount of information; as a way to increase the level of students' motivation.

Keywords: learning by correspondence, distance learning, Distance Learning Technologies, educational Internet resources, organizing the process of studying so that a student works autonomously.

В настоящее время представляется актуальным решить многие проблемы заочного обучения иностранному языку в неязыковых вузах с помощь дистанционного обучения, интегрированного в систему обучения.

Применительно к обучению иностранному языку, наиболее серьезные проблемы в системе заочного обучения возникают при овладении устными формами общения в межсессионный период. Безусловно, студент может самостоятельно практиковаться в таких видах иноязычной речевой деятельности, как чтение, письмо, аудирование. Но когда возникают проблемы устного общения, в сложившейся образовательной ситуации оно ограниченно и обычно сводится к подготовке к предстоящему устному речевому общению в учебной аудитории либо к записи своего устного ответа как части выполнения контрольных работ-заочников.

Таким образом, основными видами самостоятельной иноязычной речевой практики являются чтение, аудирование, письмо.

В условиях длительного межсессионного периода студентов-заочников, успешность их самостоятельной работы определяется не только применением средств дистанционного обучения, но и ориентацией на продуктивную учебную деятельность. $[2$, c. 23].

Продуктивная учебная деятельность обучающегося предполагает развитие у студента учебно-познавательной компетенции. «Под учебно-познавательной компетенцией понимается способность самостоятельно управлять своей учебной 
деятельностью, универсальная способность, обеспечивающая потребности образовательной деятельности в процессе овладения языком» [4, с. 84].

Далее мы рассмотрим, как средства дистанционного обучения (ДО) могут сделать работу студента в межсессионный период более эффективной. Дистанционное обучение - это процесс обучения, в котором обучающий и обучающийся географически разделены и для организации учебного процесса опираются на электронные средства и печатные пособия. К основным чертам дистанционного обучения Е.С. Полат относит [13]:

1) модульность;

2) гибкость (обучаемые работают в удобное время, темпе, месте);

3) модульность;

4) экономическая эффективность (ДО на 50 \% дешевле традиционных форм образования);

5) новая роль преподавателя: преподаватель координирует учебные группы, помогая студентам в самоопределении. Функции - управление познавательным процессом, постановка задач и их контроль, корректировка курса, консультации, руководство;

6) использование специализированных технологий и средств обучения;

7) специализированный контроль образования - использование дистанционно организованных экзаменов, собеседований, тестирующих систем.

Как было указано выше, согласно Федеральному закону «Об образовании», дистанционные образовательные технологии применяются в образовательном процессе в том числе и для повышения качества обучения.

Рассмотрим, как ДОТ могут улучшить систему заочного образования. Прежде всего, используя в $3 О$ ДОТ, взаимодействие можно осуществлять на трех уровнях: взаимодействие между обучающимся и преподавателем, взаимодействие обучающихся между собой, взаимодействие обучающихся с электронными средствами.

Взаимодействие между обучающимся и преподавателем реализуется через быстрое, не отсроченное, установление связи посредством технологии онлайн- или офлайн-консультации, используя сервис электронной почты, систему управления обучением, например, Moodle или интернет-программу JING. Представляется значимым подробно описать возможности программы JING применительно к осуществлению взаимодействия между преподавателем и студентом посредством офлайн-консультации.

Программа JING позволяет производить аудио- и видеозапись всех действий, выполняемых на экране персонального компьютера. В офлайн-консультации данная программа может применяться следующим образом: на своем рабочем столе преподаватель открывает документ, присланный студентом (эссе, вопросы по изучению материала курса), затем, включив программу, начинает запись видеоролика, в котором комментирует ошибки, рецензирует работу и / или отвечает на вопросы студента. При этом, водя курсором, преподаватель указывает на элементы, которые в данный момент комментирует.

Преимущество сокращения потраченного времени применимо также и к преподавателю, поскольку проговаривание информации занимает меньше времени, нежели ее печатание. Кроме того, взаимодействие посредством данной технологии можно назвать высокоэффективным также и потому, что в процессе прослушивания информации преподавателя студент получает дополнительную практику в аудировании, а это является, как известно, одной из самых сложных задач в обучении иностранному языку как форме межкультурного общения, особенно применительно к заочному обучению. 
Взаимодействие обучающихся с электронными ресурсами может происходить на всех уровнях работы с учебным материалом: при выполнении тренировочных (например, используя технологию лабораторной работы [3, с. 115]) и речевых упражнений, при прослушивании аудиозаписей и поиске информации, при выполнении проектов. Электронные ресурсы, с которыми обучающийся может взаимодействовать, включают в себя широкие банки учебной информации.

Учебные Интернет-ресурсы направлены на обучение студентов работать с ресурсами Интернета и могут служить не только в качестве дополнительного образовательного материала, но и в качестве аналогового или альтернативного [6]. В современной методической литературе рассматриваются пять основных типов учебных Интернет-ресурсов: хотлист (hotlist), трежа хант (treasure hunt), сабджект сэмпла (subject sampler), мультимедиа скрэпбук (multimedia scrapbook) и вебквест (webquest). Хотлист и мультимедиа скрэпбук направлены на поиск, отбор и классификацию информации. Трэжа хант, сабджект сэмпл и вебквест содержат элементы проблемного обучения.

Интеграция дистанционного обучения в систему заочного также предоставляет возможность выбора обучающимся индивидуальной образовательной траектории. Индивидуальная образовательная траектория понимается как «индивидуальный для каждого ученика путь реализации личностного потенциала в образовании» [5]. Основная концепция заключается в создании обучающимся своих личностно значимых продуктов: внутренних (развитие оргдеятельностных, познавательных, творческих и иных способностей) и внешних (написание эссе, выдвижение гипотез, осуществление вебквеста, выполнение проекта и т. п.).

Возможность высокоэффективного взаимодействия на трех уровнях, широкий доступ к банкам информации, возможность выбора студентом индивидуальной образовательной траектории положительно влияют на уровень учебной мотивации студента [3]. Использование средств дистанционного обучения также повышают активность студента, например в случае рассмотренной программы JING. В исследованиях психологов также выделяется фактор новизны материала как важнейшей предпосылки возникновения интереса к нему. Новизна материала в дистанционном обучении обеспечивается за счет постоянного обновления Интернетресурсов, которые включают в себя сайты электронных словарей, библиотек, новостных агентств и компаний. Стимулирование активной поисковой деятельности в дистанционном обучении может быть реализовано с помощью использования различных типов учебных Интернет-ресурсов (hotlist, treasure hunt, subject sampler, multimedia scrapbook, webquest) и широкий доступ к банкам информации.

$$
* * *
$$

1. Белобородова С.В. Управление самостоятельной работой студентов заочной формы обучения в вузе с использованием информационно-коммуникативных технологий: дис. ... канд. пед. наук. Петрозаводск, 2013. -169 с.

2. Бовтенко М.А. Структура и содержание информационно-коммуникационной компетенции преподавателя русского языка как иностранного: дис. ... д-ра пед. наук. - М., 2006. - 482 с.

3. Гальскова Н.Д., Гез Н.И. Теория обучения иностранным языкам. Лингво-дидактика и методика: учеб. пособие для студ. лингв. ун-тов и фак. ин. яз. высш. пед. учеб. заведений. - 5-е изд., стер. М.: Академия, 2008. - 336 с.

4. Гурьева И.И. Модернизация заочного обучения как условие повышения качества профессиональной подготовки студентов в вузе: на примере университета: дис. ... канд. пед. наук. - Ставрополь, 2007. - 205 с.

5. Дмитриева Е.И. Методические основы дистанционного обучения иноязычному чтению на базе компьютерных телекоммуникаций: дис. ... канд. пед. наук. - М., 1998. - 168 с.

6. Зимняя И.А. Педагогическая психология. - Ростов-н/Д: Феникс+, 1997. -480 с.

7. Елашкина Н.В. Формирование учебной компетенции в условиях дистанционного обучения студентов иноязычному общению: начальный этап языкового вуза: дис. ... канд. пед. наук. Иркутск, 2006. - 199 с. 